http://dx.doi.org/10.18778/8088-187-7.22

Marcin Głuszak

\title{
Szlachta przed sądami w świetle rezolucji Rady Nieustającej
}

1. Rezolucje interpretacyjne Rady Nieustającej ${ }^{1}$, której w 1776 r. przy znano kompetencję do tłumaczenia ustaw ${ }^{2}$, oprócz cennego źródła wiedzy o kondycji prawa sądowego schyłku I Rzeczypospolitej i problemach związanych z jego stosowaniem, stanowią także interesującą ilustrację postaw szlachty ${ }^{3}$ w obliczu toczących się postępowań sądowych.

Memoriały zawierające prośby o interpretację wywołujących kontrowersje przepisów prawa nadsyłali zarówno prowadzący procesy sędziowie $^{4}$, jak i spierające się przed nimi strony. Zazwyczaj jednak różne były motywy, którymi kierowali się ich autorzy. Podczas gdy urzędnicy sądowi (przynajmniej z założenia bezstronni uczestnicy postępowań) występowali do Rady Nieustającej w związku z rzeczywistymi wątpliwościami natury prawnej, szukając w niej oparcia dla wydawanych przez siebie decyzji, to strony sporów starały się przedstawiać w memoriałach swoje racje i sugerować własną interpretację prawa w sposób, który miał przekonać Radę do wydania korzystnej dla nich rezolucji. W tego rodzaju przypadkach celem autorów nadsyłanych wniosków było uzyskanie oficjalnego urzędowego potwierdzenie proponowanej w memoriale wykładni spornego przepisu.

2. Problematyka szeroko rozumianego prawa procesowego była przedmiotem ponad 200 memoriałów, czyli blisko 30\% wszystkich zapy-

${ }^{1}$ Zob. M. Głuszak, Rezolucje interpretacyjne Rady Nieustajacej, CPH, 2013, t. LXV, z. 2, s. 73-101; Zbiór rezolucji interpretacyjnych Rady Nieustajacej z lat 1786-1788, oprac. M. Głuszak, Łódź 2014.

${ }^{2}$ VL, t. VIII, fol. 850.

${ }^{3}$ Znamienne jest, że w grupie składających zapytania do Rady Nieustającej dominowała szlachta. Mieszczanie, głównie urzędnicy magistratów, stanowili w niej odsetek wielkości niecałych 3\%, M. Głuszak, Rezolucje..., s. 77.

${ }^{4} \mathrm{~W}$ gronie urzędników sądowych składających zapytania do Rady byli również między innymi podsędkowie, pisarze, burgrabiowie, podstarości, komornicy. Tamże, s. 77. 
tań, jakie kierowano do Rady Nieustającej w związku z wątpliwościami rodzącymi się przy interpretacji przepisów ${ }^{5}$. Zdecydowana większość $z$ nich pojawiła się $w$ trakcie toczących się już przed sądem spraw, niejednokrotnie zmuszając sąd do wstrzymania procesu do czasu zajęcia stanowiska przez Radę Nieustającą.

2.1. Watpliwości, które stwarzały pole do odmiennych interpretacji przepisów pojawiały się już na etapie samego ustalania właściwości rzeczowej sądu. W przesłanym do Rady Nieustającej raporcie krzemieniecki sąd ziemski poruszył problem ustalenia jurysdykcji właściwej dla rozpatrywania spraw o pierwszeństwo $\mathrm{w}$ zaspokajaniu wierzytelności zabezpieczonych na dobrach ziemskich. Przyczyną zgłoszenia były wątpliwości prawne, które, jak zasugerowano, dłużnicy wykorzystywali w celu unikania spłaty długu. Powoływali się przy tej okazji na przepisy konstytucji „Trybunał Koronny” z roku 1676, stanowiącej, że „sprawy potioritatis [...] nie wdając się w taksy Trybunały sądzić mają"6, i wskazywali jako kompetentny w tym zakresie sąd trybunalski, co oczywiście, biorąc pod uwagę jego obciążenia, wydłużało postępowanie. Krzemienieccy sędziowie poinformowali Radę, że „trafia się jednak, iż niektórzy dłużnicy, acz w jednym powiecie dobra mający, na zwłokę sprawiedliwości uczyniwszy manifest jakoby w porządku odstąpienia substancyi albo dożywocia, z ziemstw i grodów do Trybunału zyskują odesłania, a sami trzymając substancję, spraw odesłanych do Trybunału nie popierają". Autorzy raportu przywołali jednocześnie poprzednie rezolucje Rady nakazujące rozpatrywanie tego rodzaju spraw przez Trybunał, ale tylko w przypadkach, gdy dobra dłużników leżały w różnych ziemiach i województwach ${ }^{7}$. Zdaniem sądu krzemienieckiego, wspomniana konstytucja z 1676 r. nie stała na przeszkodzie wierzycielom chcącym dochodzić swoich praw w sądzie ziemskim, jeśli obciążone nieruchomości dłużnika w całości leżały w obrębie jednego powiatu, zwłaszcza że konstytucja "Złączenie Trybunału Koronnego" z 1768 r. nakazywała wszystkie sprawy w pierwszej kolejności rozpatrywać w ziemstwach i grodach ${ }^{8}$. Niemniej dla akceptacji swojej interpretacji wspomnianej konstytucji sędziowie sądu krzemienieckiego zapytali Radę, czy „w osądzenie spraw potioritatum wdawać się mają lub nie?" Rada Nieustająca potwierdziła, że jej wcześniejsze rezolucje „rozumiane być mają o sprawach potioritatis $\mathrm{z}$ dóbr dłużnika w kilku województwach leżących wynikających, kiedy

${ }^{5}$ Tamże, s. 81; Zbiór rezolucji..., s. 313-314.

${ }^{6} \mathrm{VL}, \mathrm{t} . \mathrm{V}$, fol. 357.

${ }^{7}$ Rezolucja nr 231 z 24 VI 1777, AGAD, tzw. Metryka Litewska [dalej: ML] VII, 206, k. 287 v.-291 v. i nr 239 z 19 VIII 1778 r. AGAD, tzw. ML, VII, 21, k. 516-516 v.

${ }^{8}$ VL, t. VII, fol. 703. 
zaś dobra wszystkie dłużnika in potioritatem idące pod jurysdykcję jednego tylko ziemstwa znajdują się, tak iż pod inną jurysdykcją dóbr nie ma, na ten czas sprawa potioritatis primo intuitu podług przepisu prawa 1768 roku w ziemstwie sądzona być powinna" ${ }^{\prime \prime}$. Rada Nieustająca opowiedziała się więc po stronie wierzycieli. Było to racjonalne i ważne $\mathrm{z}$ ich punktu widzenia rozstrzygnięcie, przyznające im $\mathrm{w}$ sporach $\mathrm{z}$ dłużnikami atut, umożliwiający sprawniejsze dochodzenie swoich roszczeń na szczeblu lokalnym, bez potrzeby kierowania spraw do sądu trybunalskiego.

Kontrowersje wokół właściwości sądu pojawiły się także w związku z memoriałem urzędników grodu chęcińskiego. Jak ujęli to w swoim piśmie do Rady: „strony, jedna primo et originaliter pozywa do grodu i tam, lubo druga przeciwna excypuje się a foro, w sądzie jednak tym grodzkim toż forum uznane bywa: przeto, strona pozwana wzdawać się dopuściwszy dla samej zwłoki idzie do ziemstwa, ziemstwo nie zważając na prewencję znowu sobie przyznaje forum". Działanie strony pozwanej - co wyraźnie podkreślono - miało na celu wyłącznie odwlekanie momentu skutecznego wszczęcia procesu. Skutki takich działań były wysoce niekorzystne dla obu stron, mogły prowadzić bowiem do podwójnego procesu, rezultatem czego mogły być dwa różne wyroki w tej samej sprawie. Do Rady wpłynęło więc zapytanie: „taka sprawa, czyli przyzwoiciej w ziemstwie, jak w grodzie, sądzona być ma? Lub też, podług prawa w grodzie, gdzie się zaczęła i zapadł już proces?" W rezolucji wyjaśniono, że obowiązujące prawo wyraźnie wskazuje właściwość rzeczową poszczególnych sądów, w sprawach zaś - jak dodano - „z natury swojej w ziemstwie lub grodzie sądzić się mogących $w$ takim razie podług słów prawa $1768 \mathrm{r}$. [...] która strona pierwej drugą pozwie, w tym sądzie rozprawić się maja gdzie pierwej pozew zaszedł"10. Rozwiązanie to zgodne było z zasadą pierwszej ręki (ius praeventionis) - polegającej na tym, że z kilku sądów kompetentnych, właściwy był ten, do którego sprawa została wniesiona wcześniej ${ }^{11}$. Także $\mathrm{w}$ tym przypadku rezolucja stawiała tamę działaniom obliczonym wyłącznie na zwłokę, czyniąc ważny krok w kierunku przyspieszenia postępowania i zapobiegania przypadkom prowadzenia dwóch konkurencyjnych postępowań w tej samej sprawie.

2.2. Działaniem na zwłokę $\mathrm{w}$ trakcie postępowania sądowego mogło być wykorzystywanie przewidzianych przez prawo dylacji i składanie wniosków skutecznie paraliżujących sprawny przebieg procesu. Ze skargą na tego rodzaju postępowanie wystąpił do Rady Nieustającej sąd ziemski kaliski informując ją że „wdowy niektóre dożywocia mające, unikając

\footnotetext{
${ }^{9}$ Rezolucja nr 239 z 14 XII 1781 r., AGAD, tzw. ML, VII, 37, k. 83-84.

${ }^{10}$ Rezolucja nr 43 z 1 III 1785 r., AGAD, tzw. ML, VII, 53, k. 89-91.

${ }^{11}$ J. Sondel, Słownik łacińsko-polski dla prawników i historyków, Kraków 2005, s. 782.
} 
rozsądzenia, najprzód żądają dilationem komunikacyi dokumentów na fundamencie konstytucyi 1768, po tej wyszłej domagają się wyznaczenia minorennibus opiekunów, dalej pretendują aby miały przydanego kuratora, i tak pięć kadencyi samymi dylacjami z konstytucyi wyżej wzmiankowanej wynikającymi, wierzycielów przedłużają". Działania wyżej opisane, ukierunkowane na odroczenie postępowania, były jak wspomniano dopuszczane przez prawo ${ }^{12}$. Dlatego kluczowe, zdaniem autorów memoriałów, było wyjaśnienie regulującej uprawnienia wdów wspomnianej ustawy. Szukając w Radzie pomocy dla ukrócenia wspomnianych praktyk i podstępnego - jak sugerowano - wykorzystywania odkładów, autorzy memoriału dopytywali się: "czyli więc wdowy utrzymujące się przy dożywociu, mogą żądać opiekunów i kuratorów? I czyli wdowy w sprawach uczynkowych już za wdowieństwa wynikłych, powinny używać dylacyi wyznaczenia kuratora?" Konsyliarze odpowiedzieli, że przywileje wynikające z konstytucji 1775 r. nie uprawniają wdów, aby „dla zwłoki sprawiedliwości żądając dodania opiekunów albo kuratorów, do dylacyi onych dodania zabierały się", i wyjaśnili, że w myśl wspomnianej ustawy można przydzielić wdowom opiekunów i kuratorów, a „odciąwszy nieprawnie żądaną dylację" prowadzić dalsze postępowanie ${ }^{13}$.

2.3. O innej praktyce zmierzającej do sparaliżowania procesu, doniósł Radzie sędzia ziemski sieradzki Paweł Załuskowski ${ }^{14}$. Problem dotyczył wyłączania z postępowania dowodowego świadków, których zeznania mogły być niekorzystne dla jednej ze stron. Załuskowski zasygnalizował, że „zagęściło się już, gdzie inkwizycje zachodzą w małej wiosce, pozwa-

${ }^{12}$ Chodziło o konstytucje: "Złączenie Trybunału Koronnego", VL, t. VII, fol. 702 oraz „Ubezpieczenie sierot i wdów”, VL, t. VIII, fol. 183.

${ }^{13}$ Rezolucja nr 118 z 28 IV 1778 r., AGAD, tzw. ML, VII, 21, k. 249-252. Rozbudowany katalog dylacji często służących działaniu na zwłokę, jak wskazuje podany przykład, obejmował według T. Ostrowskiego 11 różnych dylacji. T. Ostrowski, Prawo cywilne albo szczególne narodu polskiego, t. II, Warszawa 1784, s. 36-37. Warto dodać, że szlachta, świadoma wykorzystywania dylacji w celu przeciągania procesów, wielokrotnie wypowiadała się w instrukcjach sejmikowych za ograniczeniem ich liczby, domagając się, jak np. w województwie brzesko-litewskim, „skrócenia niepotrzebnych”. Więcej przykładów podaje J. Michalski, Studia nad reforma sadownictwa i prawa sąowego w XVIII w., Wrocław-Warszawa 1958, s. 269. Z uwagi na powyższy proceder, celem wyeliminowania wspomnianej praktyki, w projekcie do Kodeksu Stanisława Augusta - autorstwa J. Morawskiego, określono możliwość odroczenia procesu jedynie w przypadku, gdy strona powołuje nowego świadka w miejsce wyłączonego. W. Szafrański, Kodeks Stanisława Augusta, Poznań 2007, s. 311.

${ }^{14}$ Paweł Załuskowski h. Rola - sieradzki regent grodzki, pisarz grodzki, sędzia grodzki, podsędek ziemski (1768), sędzia ziemski (1776-1778), Urzędnicy województw tęczyckiego i sieradzkiego XVI-XVIII wieku. Spisy, red. A. Gąsiorowski, oprac. E. Opaliński, H. Żerek-Kleszcz, Kórnik 1993, s. 308. 
ny wszystkich poddanych kładzie w proces i po tym od świadectwa ekscypuje $^{\prime 15}$. Opisany przypadek nie był odosobniony, kilka lat później sąd wizki stanął bowiem przed podobnym dylematem, pytając konsyliarzy Rady Nieustającej, jak powinien postępować odnośnie do osób, których strona "chcąc od świadectwa odsunąć, terminami czyli pozwami, do tejże sprawy ich zajmuje"16. Proceder ten znacznie utrudniał lub wręcz uniemożliwiał przeprowadzenie postępowania dowodowego, z którego udziału świadkowie, rzekomo zaangażowani w toczącą się sprawę, musieli być wykluczeni ${ }^{17}$. Tymczasem, jak sugerowali autorzy interwencji, sądy znając rzeczywiste motywy pozwanych w procesie osób, nie dysponowały narzędziami prawnymi, które pozwoliłyby zapobiegać takiemu nadużywaniu prawa. Rada Nieustająca orzekła, że „w przypadku gdyby in elusionem inkwizycyi, kto communitatem cała pozywał, a zatym a deponendo testimonio excypował, w ten czas sąd kondescensję wyznaczający, może pozwolić wybrać świadków z pozwanych, jednak in complicitatem facti nie wchodzących i wyraźnymi prawami excypować się nie mogących". Konsyliarze uznali zatem, że określenie statusu poszczególnych osób w danej sprawie i decyzja o dopuszczeniu ich do złożenia zeznań w charakterze świadków należeć powinna do organu sądowego, i to w jego gestii leży ograniczenie opisywanych praktyk.

Również związaną ze świadkami, nienależącą jak się wydaje do rzadkości, praktykę opisał Radzie Nieustającej Karol Wąsowicz - sędzia ziemstwa radomskiego ${ }^{18}$, który w przygotowanym przez siebie raporcie wskazał przypadki, gdy strony biorące udział $\mathrm{w}$ trwających nierzadko wiele lat sąsiedzkich sporach ziemskich, w obawie „,aby świadkowie laty obciążeni nie pomarli przed dokończeniem procesu granicznego [...] świadków takowych do grodu stawiwszy, ich zeznania, aby były zaprzysię-

\footnotetext{
${ }^{15}$ Rezolucja nr 362 z 14 X 1777 r., AGAD, tzw. ML, VII, 206, k. 476 v.-478 v.

${ }^{16}$ Rezolucja nr 281 z 14 III 1786 r., AGAD, tzw. ML, VII, 57, k. 211-211 v.

${ }^{17}$ Przeciwnik procesowy miał prawo przyjęcia (acceptatio testum) lub odrzucenia świadków (tzw. niezdolnych) z uzasadnionej przyczyny. Musiał jednak złożyć takie oświadczenie $\mathrm{w}$ chwili przedstawienia kandydatów na świadków. Nie mógł żądać wyłączenia świadków, którzy wcześniej przez niego zaakceptowani, zostali już zatwierdzeni i zapisani przez sąd. Świadkiem niezdolnym była między innymi osoba, która sama brała udział w sprawie. O. Balzer, Przewód sądowy polski w zarysie, Lwów 1935, s. 164, 170; J. Rafacz, Dawny proces polski, Warszawa 1925, s. 165. Praktyka nieuzasadnionego wyłączenia świadków przez stronę przeciwną była zjawiskiem dość często spotykanym. Aby temu zapobiec, w projekcie do Kodeksu Stanisława Augusta przewidziano za tego typu działania karę pieniężną w wysokości 50 zł, którą ponosił wyłączający na rzecz świadka, W. Szafrański, Kodeks..., s. 311.

${ }^{18}$ Karol Dunin Wąsowicz h. Łabędź - podsędek (1765-1775) i sędzia radomski (17751793), Urzędnicy województwa sandomierskiego XVI-XVIII wieku. Spisy, red. A. Gąsiorowski, oprac. K. Chłapowski, A. Falniowska-Gradowska, Kórnik 1993, s. 221.
} 
żone, starają się". Z pisma Wąsowicza wynika, że strony jako podstawę swojego działania powoływały konstytucję z roku 1588 „O mężobójcach i skrutyniach i wieży". Taki sposób działania, choć z punku widzenia zainteresowanych stron był zrozumiały i miał zabezpieczyć ich interes w toczącej się sprawie, budził sporo kontrowersji. Przepisy wspomnianej konstytucji traktowane były $\mathrm{w}$ tym wypadku w sposób wybiórczy. Bo choć przewidywały one, że „wolno będzie w swoim grodzie przed urzędem starościm [...] świadectwo swe obyczajem wyżej opisanym dać" ${ }^{19}$, to złożenie zeznania, przy zachowaniu wszelkich ukształtowanych zwyczajowo reguł rządzących postępowaniem dowodowym, powinno nastąpić w odpowiednich okolicznościach, we właściwym czasie, po uprzednim powołującym świadków postanowieniu sądu. Mimo to Wąsowicz poprosił Radę o wyjaśnienie obiekcji, które wyraził pytając "czyli więc sąd, takowe świadectwa ma uchylić, lub potwierdzić?" Treść rezolucji nie pozostawiała żadnych wątpliwości, uznano w niej opisywane działania stron za niezgodne z prawem, a konstytucja „wszelkie świadectwa za poprzedzającym tylko sądowym wyrokiem na stawienie przez obydwie strony świadków [...] i za poprzedzająca przez obydwie strony super incorruptionem przysięgą wykonane mieć chce i dopiero do nich ważność przywiązuje" ${ }^{\prime 20}$.

O trudnościach związanych z postępowaniem dowodowym pisał Radzie Nieustającej Władysław Ciołkowski - sędzia grodu stężyckiego. Doniósł on o praktykowanym przez lichwiarzy procederze, któremu sądy nie potrafiły skutecznie zaradzić. Autor memoriału przypomniał, że zgodnie z ustawą z roku 1775 potwierdzony został zakaz pobierania zawyżonego procentu od pożyczek, a dla osób łamiących to prawo przewidziano karę wysokiej grzywny ${ }^{21}$. W uchwalonej w tym samym roku konstytucji „Dochody skarbowe Obojga Narodów"22, w rozdziale poświęconym obowiązkowi zawierania transakcji na papierze stemplowanym, znalazł się warunek nakazujący, aby „,żaden dokument na papierze niepiętnowanym zapisany, żadnego waloru, w żadnym sądzie nie miał i przyjęty nie był"23. Ciołkowski zwrócił uwagę na sposób działania nie-

${ }^{19} \mathrm{VL}, \mathrm{t} . \mathrm{II}$, fol. 1215.

${ }^{20}$ Rezolucja 242 z 26 XI 1783, AGAD, tzw. ML, VII, 50, k. 9-12.

${ }^{21}$ Ciołkowski miał prawdopodobnie na myśli konstytucję „Ustanowienie prowizyi i ubezpieczenie kredytorów”, zgodnie z którą "debitorowie swoim kredytorom więcej płacić obligowani nie będa, tylko pięć od sta na rok i ktoby z kredytorów większej wyciągał prowizyi, karą 500 grzywien i utraceniem rocznej prowizyi karany być ma", VL, t. VIII, fol. 181.

${ }^{22}$ Zwracający się do Rady sędzia błędnie wspomniał, że ustawa o opłacie stemplowej została uchwalona w roku 1776.

${ }^{23}$ VL, t. VIII, fol. 146. 
uczciwych wierzycieli. Wyjaśnił, że „lichwiarz, aby dowodu lichwy nie było, pożyczając pieniędzy na zastawę rzeczy, nie bierze dokumentu na pieniądze dane i wymuszoną lichwę na papierze stemplowanym, lecz na prostym". Działanie przynosiło zamierzony skutek, bo - jak tłumaczy autor memoriału - w przypadku skierowania sprawy na drogę sądowa, ",sąd przychylając się do prawa o stemplowanym papierze uchwalonego, nie przyznaje owego dokumentu za dowód, jako na papierze niestemplowanym będącego i uwalnia od kary lichwiarza". Z opisu przedstawionego przez Ciołkowskiego wynika, że sądy skrupulatnie podchodziły do przestrzegania konstytucji o papierze stemplowanym, ale wobec dopuszczających się lichwy były bezsilne, pozwalając na uniknięcie przez łamiących w tym zakresie prawo osób przewidzianej ustawą kary. Stąd skierowane do Rady pytanie - „czyli więc, w takim przypadku, prawo 1775 roku o lichwach postanowione, bez exekucyi zostać powinno?" Rada Nieustająca znalazła rozwiązanie problemu orzekając, że sąd powinien uznawać za ważne wyłącznie transakcje zawarte na papierze stemplowanym, stwierdziła jednak równocześnie obowiązek karania lichwiarzy, lichwa bowiem „czy na papierze stemplowanym, czy na prosto używanym wymuszoną okaże się, zawsze jest lichwą"24.

2.5. Jednym ze sposobów opóźniania zakończenia procesu było składanie przez strony wniosków o apelację od każdego postanowienia sądu pierwszej instancji. Fakt ten odnotował i przedstawił Radzie Tadeusz Kociełło - starosta sądowy oszmiański ${ }^{25}$, przypominając równocześnie, że konstytucja z roku 1726 "Sprawy in minori subsellio niedrabowane" przewidywała wysokie kary grzywny i wieży za niezgodne z prawem składanie apelacji ${ }^{26}$, a kolejna, uchwalona w $1764 \mathrm{r}$. poświęcona tej kwestii ustawa „O apelacjach” zakazała odwoływania się od dekretów akcesoryjnych, a więc niefinalnych ${ }^{27}$. Niestety $\mathrm{w}$ przypadku drugiej $\mathrm{z}$ przywołanych konstytucji można mówić o niekonsekwencji lub przeoczeniu jej autorów. W tym również Kociełło upatrywał przyczyn nagminnego utrudniania prowadzenia postępowania. Ponieważ - jak stwierdził - „późniejsza wyżej wspomniona roku 1764 konstytucja wyraźnie jej nie reasumuje [kon-

${ }^{24}$ Rezolucja nr 209 z 10 X 1783 r., AGAD, tzw. ML, VII, 48, k. 182-182 v.

25 Tadeusz Kociełło (Kocioł) h. Pelikan - starosta markowski, starosta sądowy oszmiański (1772-1799). Urzędnicy Wielkiego Księstwa Litewskiego. Spisy, t. I: Województwo wileńskie XIV-XVIII wiek, red. A. Rachuba, oprac. H. Lulewicz, A. Rachuba, P. P. Romaniuk, współpr. U. Jemialianczuk, A. Macuk, Warszawa 2004, s. 301, 670.

${ }^{26}$ "Zabiegając his inconvenientijs na tych, którzy [...] od sprawiedliwych dekretów temere apeluja, winy na same strony po kop czterdzieści partii injuriatae, cum poena sessionis turris naznaczamy", VL, t. VI, fol. 482.

${ }^{27}$ "Apelacje a minoribus subselliis [...] post latum tylko finale in principali negotio decretum, in omni modestia, podług statutu czynione być mają", VL, t. VII, fol. 394. 
stytucji z roku 1726 - M.G.], ani innej naznacza kary, odważają się strony i ich prokuratorowie, z wielkim sądowego czasu zagajeniem, od każdej akcesorialnej decyzyi apelować, która apelacja, chociaż podług prawa nie bywa dopuszczona, sąd jednak w dawaniu rezolucyi, zatrudnieniu ulegać musi". Ze słów starosty wynika, że działający na zwłokę uczestnicy procesu, choć zdawali sobie sprawę, że wnioski przez nich przedkładane będą odrzucane, przeświadczeni byli równocześnie, iż kierując się wyłącznie postanowieniami ustawy z roku 1764, sędziowie nie zdecydują się na wymierzenie im kar. Brak wyraźnie wskazanych w nowej konstytucji prawnych sankcji dla stron apelujących wbrew prawu, utrzymywał je w poczuciu bezkarności, umożliwiając składanie wniosków, do których sąd zmuszony był się ustosunkować, co skutecznie spowalniało cały proces. Choć zdaniem autora interwencji „konstytucja roku 1764 [...] strony apelujące $a b$ accessorio karać, podług przepisu konstytucji 1726 roku, obowiązywać zdaje się", problem ten budził jednak pewne wątpliwości, skoro Kociełło zdecydował się zwrócić o wyjaśnienie owej kwestii do Rady Nieustającej. Ta stwierdziła, że zgodnie z powoływaną konstytucją z 1764 r. sądy pierwszej instancji mają jedynie prawo nie dopuszczać apelacji, moc zaś karania "stron uporczywie apelujących” jest kompetencją jurysdykcji wyższego szczebla, do której niezgodne z ustawą odwołanie zostało złożone ${ }^{28}$.

Inny przykład niezgodnego z prawem odwoływania się od wyroków sądowych przedstawił Radzie sędzia Paweł Załuskowski ${ }^{29}$, który zaobserwował powszechne, jak wynika z jego relacji, zjawisko niezgodnego z prawem składania apelacji. Załuskowski doniósł konsyliarzom, że choć „prawo jest, aby z grodów do ziemstw nie szły apelacje, wiele jest takich pacjentów, co w grodzie mocyi nie czynia, a potym contra decreta castrensia wydają do ziemstwa prozekucje". Na czym polegała w tym przypadku różnica między mocją i apelacją ${ }^{30}$ a prozekucją? Apelacja dotyczyła zaskarżenia wyroku sądu niższej instancji - w opisywanej tu sytuacji - sądu grodzkiego do instancji wyższej - Trybunału Koronnego. Jak powszechnie było wiadomo, zgodnie ze zwyczajem potwierdzonym przez konstytucję "Złączenie Trybunału Koronnego" z roku 1768, obowiązywał, wynikający z gradacji jurysdykcji, ścisły zakaz apelowania z grodu do ziemstwa ${ }^{31}$

${ }^{28}$ Rezolucja nr 70 z 13 III 1778 r, AGAD, tzw. ML, VII, k. 141-142.

${ }^{29}$ Zob. przyp. 14.

${ }^{30}$ Prawdopodobnie w opisywanym przypadku mocja była utożsamiana z apelacją. Podobnie przyjmuje J. Kitowicz, Opis obyczajów za panowania Augusta III, oprac. R. Pollak, Wrocław 1950, s. 229.

${ }^{31}$ Zgodnie z zasadą par super parem non habet potestatem, Tamże. 
(z wyjątkiem województwa łęczyckiego) ${ }^{32}$ - a więc sądów tzw. niższych, znajdujących się na tym samym poziomie sądowniczej hierarchii ${ }^{33}$. Tymczasem, jak wynika ze słów Załuskowskiego, niezadowoleni z werdyktu sądu grodzkiego uczestnicy procesu zakaz ów łamali. Zamiast składać apelację - dopuszczaną jedynie od wyroków finalnych przez sam sąd pierwszej instancji, którego dekret był zaskarżany - do Trybunału, w którym natłok spraw i terminy oczekiwania na proces były bardzo odległe ${ }^{34}$ - prozekwowali35, a więc składali odwołania do sądu ziemskiego, nie zachowując właściwej procedury, bez pośrednictwa i z pominięciem zgody samego grodu, i w tym też ziemstwie skarżyli zapadły wyrok. Z pewnością stosujący ten wybieg liczyli na inne, pozytywne dla siebie, szybsze niż w Trybunale rozstrzygnięcie sprawy, ewentualne zablokowanie procedury egzekucyjnej prowadzonej na podstawie dekretu grodzkiego. $\mathrm{Z}$ formalnego punktu widzenia nie było więc mowy o apelacji, niemniej podejmowane przez strony działania musiały budzić zastrzeżenia co do ich zgodności z prawem. Załuskowski podzielił się swoimi wątpliwościami z Radą, pytając "czyli więc ziemstwo może się wdawać w rezolucję spraw podobnych [rozstrzygniętych już dekretem przez gród - M.G.]? Na opisane praktyki nie było oczywiście zgody Rady Nieustającej, która potwierdziła, że prawo nakazuje "gravamina jurysdykcyi w Trybunałach poznawać $[. .$.$] przeto dekretów grodzkich ani ex appellatione ani ex citatio-$ ne sądy ziemskie poznawać nie mogą"36.

O odwoływaniu się od niekorzystnego wyroku sądowego napisał także urząd grodzki lidzki. Autorzy raportu zaznaczyli na wstępie, że zgodnie z konstytucją „O sprawach minoris importantiae” z 1764 r., w celu odciążenia sądu trybunalskiego od spraw mniejszej wagi, postanowiono „ażeby w sprawach wszystkich minoris importantiae, które ex merito suo non excedunt valorum pięciuset złotych, urzędy ziemskie i grodzkie przez finalną pryncypalną $\mathrm{w}$ swoich sądach decyzję judicata ferowali, non admissa quavis appellatione" ${ }^{\prime 37}$. Mimo iż zwrot ex merito suo w sposób jedno-

\footnotetext{
${ }^{32}$ VL, t. VIII, fol. 284.

33 "Apelacje z grodu lub ziemstwa, według opisu konstytucji 1670 a sola tylko definitiva sententia dopuszczane być mają do Trybunału", VL, t. VII, fol. 703.

${ }^{34}$ Z. Kaczmarczyk., B. Leśnodorski, Historia państwa i prawa Polski, red. J. Bardach, t. II, Warszawa 1968, s. 265.

${ }^{35}$ Pojęcie „prozekucji” jest dość szerokie. Dutkiewicz utożsamia je z „odwołaniem się, czyli prowokacją via gravaminis" - cyt. za I. Szczepankowska, Język prawny I Rzeczypospolitej w "Zbiorze praw sądowych" Andrzeja Zamoyskiego, cz. I, Białystok 2004, s. 300. Czasownik "prosekwować” tłumaczono także jako „popierać sprawę”, „utwierdzać sądownie" - M. Orgelbrand, Stownik języka polskiego, Wilno 1861, s. 1209.

${ }^{36}$ Rezolucja nr 362 z 14 X 1777 r., AGAD, tzw. ML, VII, 206, k. 476 v. - 479.

${ }^{37} \mathrm{VL}$, t. VII, fol. 401.
} 
znaczny regulował tę kwestię, odnosząc się do wartości przedmiotu spo$\mathrm{ru}$, to jak donieśli urzędnicy grodu „,w komput 500 zł. winy, nawiązki, expensa prawne i same meritum sprawy, strony zaliczać zwykły i apelacyi dopraszają się". Świadoma nadinterpretacja przepisu konstytucji, wbrew założeniom prawodawcy, umożliwiała stronom przegrywającym proces w niższych instancjach przeciąganie całej sprawy i kontynuowanie jej w Trybunale. Oczywiście takie tłumaczenie ustawy wzbudzało wątpliwości urzędników, którzy szukając w Radzie wyraźnej odpowiedzi zapytali „,czy od kar, win niestannych, nawiązek i expensów prawnych z niej wynikających, wolna ma być apelacja?" Żadnych obiekcji nie miała natomiast Rada Nieustająca, która uznała prawo za jasne, tłumacząc, że gdy „meritum sprawy czyli szacunek negotii principalis sumy 500 zł. nie przechodza praecisa appellatione [bez dopuszczenia apelacji - M. G.] w sądach primae instantiae sądzone być powinny" 38 .

2.6. Próby poszukiwania nieścisłości w przepisach prawa umożliwiających odniesienie korzyści następowały także na etapie postępowania egzekucyjnego. Świadczy o tym raport urzędu grodzkiego kijowskiego. Wynika z niego, że skuteczny sposób unikania sądowej egzekucji znaleźli nieuczciwi dłużnicy, którzy - jak czytamy - „w sprawach liquidi debiti chroniąc się a judicato w grodzie, dla zyskania obstante cognitione remissy, manifesta contra jura petendi oponują". Zgodnie z konstytucją sejmową "Złączenie Trybunału Koronnego" z 1768 r., urzędy grodzkie obowiązywał zakaz kognicji - czyli rozpoznawania zawartych między stronami transakcji odnośnie do ich meritum ${ }^{39}$. Dłużnicy skrupulatnie powoływali się na ów przepis i mając świadomość braku kompetencji grodu w tym zakresie, w chwili skierowania do niego sprawy na drogę egzekucji, składali tam protestacje - oświadczenia sądowe o naruszeniu ich praw, kwestionujące legalność transakcji. Jednocześnie żądali odesłania sprawy w celu ponownego rozpoznania zawartej umowy do właściwej, wyposażonej w takie uprawnienia jurysdykcji. Urzędy grodzkie natomiast $\mathrm{w}$ obawie przed sankcjami przewidzianymi za złamanie rygorów wspomnianej ustawy, wzbraniały się przed kognicją sprawy, wstrzymując jednocześnie dalsze postępowanie egzekucyjne. Tym prostym zabiegiem dłużnicy osiągali swój cel, odraczając moment egzekucji. Jedyną skuteczna, zdaniem autorów raportu, receptą na tego rodzaju unikanie odpowiedzialności było zaproponowane przez nich rozszerzenie kompetencji sądów starościńskich. Zapytali więc "czyli nie można grodom pozwolić, władzy cognitionis w sprawach dziesięciu tysięcy złotych nie

${ }^{38}$ Rezolucja nr 71 z 5 II 1779 r., AGAD, tzw. ML, VII, 26, k. 5-6.

${ }^{39}$ "A grody w sprawy ziemskie, które supiunt cognitionem wszelkich transakcyi, i manifestów ullo modo wdawać się nie mają, sub poena 1000 marcarum", VL, t. VII, fol. 703. 
przenoszących, zwłaszcza gdy prawo 1768 roku transakcje legalnie nastąpione [zatwierdzone urzędowo - M. G.] utwierdzając, w przypadku onych odwołania, wszelkiej kognicyi zabrania?" Rada, której kompetencje nie pozwalały na zmianę obowiązującego prawa, nie podjęła tematu rozszerzenia uprawnień grodów, potwierdziła jedynie ustawowy zakaz badania przez nie ważności umów, nakazując ",ażeby tylko legalne transakcje etiam obstante reclamatione kognicyi nie podlegały, przez co kognicja (czy legalnie lub nielegalnie nastąpiona transakcja) nie jest zniesiona" ${ }^{40}$.

Także wierzyciele szukali w prawie rozwiązań sprzyjających $-\mathrm{w}$ ich przypadku - przeprowadzeniu szybkiej egzekucji. Przykładem jest sprawa Ksawerego Chojeckiego, który po wygraniu procesu w sądzie ziemskim żytomirskim uzyskał dekret egzekucyjny, służący za podstawę do przeprowadzenia tradycji na nieruchomości strony przeciwnej. Warto przypomnieć, że w myśl konstytucji „Decreta executionis” z roku 1784, w dekrecie egzekucyjnym należało w sposób szczegółowy wymienić dobra ziemskie takiej egzekucji podlegające ${ }^{41}$. Tymczasem, jak wynika z treści rezolucji, wyrok którym dysponował Chojecki „,nie wyrażając specifice dóbr, przepisuje tylko, iż te na których były kładzione pozwy, podlegają exekucyi". Z tak sporządzonym tytułem egzekucyjnym, powód udał się do Departamentu Wojskowego Rady Nieustającej żądając przydzielenia oddziału wojska mającego zabezpieczyć przeprowadzenie tradycji. Urzędnicy departamentu stanęli przed dylematem, bo choć przewidziane w sejmowej ustawie warunki formalne dla dekretu egzekucyjnego nie zostały spełnione, dążący do zajęcia nieruchomości Chojecki przedstawił własną interpretację wspomnianego prawa. Jak donieśli członkowie Departamentu Wojskowego, zainteresowany "twierdzi, iż lubo w dekrecie executionis nie masz wyrażonych specifice dóbr, z okoliczności procesu wszystkich obywatelów i urzędników obejmującego, lecz gdy strona aktorowa próbując konwikcję dóbr tych, do których pomocy wojskowej żąda, extrakty pozwów pokłada, przeto pomoc wojskowa, dodaną być powinna". Rada Nieustająca nie przychyliła się do sugestii Ksawerego Chojeckiego i powołując się na wydaną już wcześniej własną rezolucję z $1785 \mathrm{r}^{42}$ uznała, że żądana przez niego pomoc wojskowa nie może być przydzielona. Wyjaśniono, że ustawa z 1784 r. miała na celu ochronę osób trzecich, aby "dobra cudze inwolwowane nie były" ${ }^{43}$. Rada stanęła zatem na straży obowiązujących przepisów, odrzucając możliwość prowadze-

${ }^{40}$ Rezolucja nr 231 z 24 VI 1777 r., AGAD, tzw. ML, VII, 206, k. 288-291 v.

${ }^{41}$ „Pomienione dekreta executionis następować maia z wyrażeniem specifice dóbr ruchomych lub nieruchomych, do których tradycya ściągać się ma", VL, t. IX, s. 16.

${ }^{42}$ Rezolucja nr 241 z 30 XII 1785 r., AGAD, tzw. ML, VII, 57, k. 148-148 v.

${ }^{43}$ Rezolucja nr 266 z 10 II 1786 r., AGAD, tzw. ML, VII, 57, k. 188-189. 
nia egzekucji na podstawie błędnie sporządzonego dekretu egzekucyjnego, nawet jeśli okoliczności sprawy, jak twierdził Chojecki, uzasadniały zajęcie nieruchomości.

3. Brak w Koronie kompleksowej kodyfikacji prawa procesowego ${ }^{44}$ i działanie na podstawie zwyczaju oraz uchwalanych dla różnych prowincji, ziem i województw na przestrzeni kilkudziesięciu, a nawet kilkuset lat pojedynczych konstytucji sejmowych, które w niewielkim stopniu regulowały wybrane instytucje procesowe, sprawił, że postępowanie przed sądami szlacheckimi w wieku XVIII było utrudnione. Znaczenie miał również fakt, że niektóre ze wspomnianych ustaw napisane zostały w sposób niejasny i zawiły. Dawały więc sposobność do nadinterpretacji zawartych w nich przepisów. Niemniejszy wpływ na przebieg postępowań sądowych miała sama postawa i działania podejmowane przez jej uczestników. W dążeniu do uniknięcia odpowiedzialności lub osiągnięcia innych określonych korzyści szukano w prawie luk i nieścisłości, wykorzystywano niedoskonałości systemu, a na przepisy powoływano się wybiórczo. Stąd wszelkiego rodzaju obstrukcje i czynności, których celem było odroczenie terminów, wydłużenie procesu czy wstrzymanie egzekucji. Sądy, jak widać po zaprezentowanych wyżej przykładach rezolucji, nie zawsze potrafiły znaleźć na takie działania receptę, zwracały się więc do wszechwładnej, jak powszechnie uważano, Rady Nieustającej, której rola w tym zakresie, choć prawo nie przyznało jej kompetencji ustawodawczych, nie ograniczała się tylko do oceny zgodności określonego działania z obowiązującymi przepisami. Rada starała się wyjaśniać i sugerować sądom rozwiązania problematycznych sytuacji. I mimo że rezolucje nie zawsze pozwalały rozwiązać kwestię wadliwego prawa i zapobiec opisywanym praktykom stron, stanowiły dla sądów fundament wyroku, który - choćby z racji autorytetu Rady Nieustającej - trudniej było kwestionować.

\section{Bibliografia}

Źródła rękopiśmienne

AGAD, tzw. Metryka Litewska, dział VII.

\section{Źródła drukowane}

Kitowicz J., Opis obyczajów za panowania Augusta III, oprac. R. Pollak, Wrocław 1950.

${ }^{44}$ Nie licząc przyjętej przed ponad 250 laty w dużej części anachronicznej Formula Processus. 
Ostrowski T., Prawo cywilne albo szczególne narodu polskiego, t. II, Warszawa 1784. Volumina Legum, t. II, V, VI, VII, VIII, IX, Przedruk Zbioru Praw, wyd. J. Ohryzko, Petersburg 1859-1860.

Zbiór rezolucji interpretacyjnych Rady Nieustającej z lat 1786-1788, oprac. M. Głuszak, Łódź 2014.

\section{Opracowania}

Balzer O., Przewoód sądowy polski w zarysie, Lwów 1935.

Głuszak M., Rezolucje interpretacyjne Rady Nieustajacej, CPH, 2013, t. LXV, z. 2.

Kaczmarczyk Z., Leśnodorski B., Historia państwa i prawa Polski, red. J. Bardach, t. II, Warszawa 1968.

Michalski J., Studia nad reforma sadownictwa i prawa sadowego w XVIII w., WrocławWarszawa 1958.

Orgelbrand M., Słownik języka polskiego, Wilno 1861.

Rafacz J., Dawny proces polski, Warszawa 1925.

Sondel J., Słownik łacińsko-polski dla prawników i historyków, Kraków 2005.

Szafrański W., Kodeks Stanistawa Augusta, Poznań 2007.

Szczepankowska I., Język prawny I Rzeczypospolitej w "Zbiorze praw sadowych" Andrzeja Zamoyskiego, cz. I, Białystok 2004.

Urzędnicy Wielkiego Księstwa Litewskiego. Spisy, t. I, Województwo wileńskie XIVXVIII wiek, red. A. Rachuba, oprac. H. Lulewicz, A. Rachuba, P. P. Romaniuk, współpr. U. Jemialianczuk, A. Macuk, Warszawa 2004.

Urzędnicy województw tęczyckiego i sieradzkiego XVI-XVIII wieku. Spisy, red. A. Gąsiorowski, oprac. E. Opaliński, H. Żerek-Kleszcz, Kórnik 1993.

Urzędnicy województwa sandomierskiego XVI-XVIII wieku. Spisy, red. A. Gąsiorowski, prac. K. Chłapowski, A. Falniowska-Gradowska, Kórnik 1993. 